\title{
The zooplankton biodiversity of some freshwater environments in Parnaíba basin (Piauí, Northeastern Brazil)
}

\author{
Paranhos, JDN. ${ }^{a}$, Almeida, VLS. , Silva Filho, JP. ${ }^{a}$, Paranaguá, MN.c, \\ Melo Júnior, $M^{d *}$ and Neumann-Leitão, S. $^{e}$

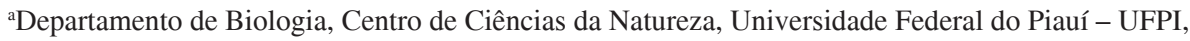 \\ Campus Ministro Petrônio Portella, Ininga, CEP 64049-550, Teresina, PI, Brazil

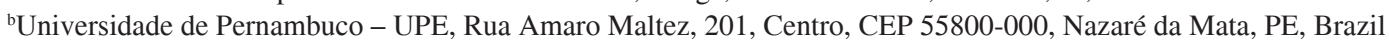 \\ 'Departamento de Biologia, Universidade Federal Rural de Pernambuco - UFPE, \\ Av. Dom Manuel de Medeiros, s/n, Dois Irmãos, CEP 52171-900, Recife, PE, Brazil \\ ${ }^{d}$ Laboratório de Ecologia do Plâncton - LEPLANC, Universidade Federal Rural de Pernambuco - UFRPE, \\ Unidade Acadêmica de Serra Talhada, Estrada para a Fazenda Saco, s/n, \\ Zona Rural, CEP 56903-970, Serra Talhada, PE, Brazil

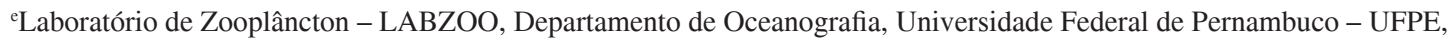 \\ Av. da Arquitetura, s/n, Cidade Universitária, CEP 50740- 550, Recife, PE, Brazil \\ *e-mail: mmelojunior@gmail.com
}

Received February 14, 2012 - Accepted April 26, 2012 - Distributed February 28, 2013

(With 4 figures)

\begin{abstract}
The plankton fauna of the state of Piauí, Northeastern Brazil, especially in the Parnaíba basin, is still poorly known; the results of most studies of the subject have not been published and can only be found in grey literature (unpublished scientific works), such as course completion work and consulting reports. Thus, this paper presents data from samples taken recently from different water bodies in Piauí and represents the second study to be published on the region's zooplankton since the pioneering work of Spandl (1926). A total of 38 species were recorded, including 23 new occurrences of rotifers, 10 of cladocerans and 2 of copepods for the state of Piauí. The greatest richness was observed for the rotifers, of which the genus Brachionus must be highlighted, especially at the Joana reservoir. Among the crustaceans, the greatest richness was observed at the Bezerra reservoir, where cladocerans of the genus Bosmina were prominent. The rotifers Brachionus havanaensis Rousselet, 1911 and Filinia longiseta (Ehrenberg, 1834); the cladocerans Diaphanosoma spinulosum Herbst, 1967 and Moina micrura Kurz, 1874; and the copepods Notodiaptomus cearensis Wright, 1936 and Thermocyclops decipiens Kiefer, 1927 occurred in all or in most environments in which the respective groups were studied. The results presented here expand the taxonomic list of zooplankton for the state of Piauí, including a total fauna of 30 species of rotifers, 15 of cladocerans and 3 of copepods. The zooplankton richness was considered low in the studied reservoirs compared to other freshwater ecosystems from Northeastern Brazil; however, the few studies developed in the Parnaíba basin suggest that the diversity for these organisms should be higher.
\end{abstract}

Keywords: species composition, zooplankton, reservoirs, Parnaíba basin, Northeastern Brazil.

\section{Diversidade do zooplâncton de alguns ambientes de água doce na bacia do rio Parnaíba (Piauí, Nordeste do Brasil)}

\section{Resumo}

A fauna planctônica do Estado do Piauí, Nordeste do Brasil, especialmente para a Bacia do Rio Parnaíba, é ainda pouco conhecida; o resultado da maioria dos estudos não é publicado, podendo ser encontrado apenas em bibliografia cinzenta (não publicada cientificamente), tais como trabalhos de finalização de curso e relatórios de consultorias. Assim, o presente trabalho apresenta dados de amostragens recentes realizadas em diferentes corpos d'água do Piauí, consistindo no segundo estudo publicado sobre o zooplâncton da região, após o trabalho pioneiro de Spandl (1926). Registrou-se um total de 38 espécies, incluindo 23 novas ocorrências de rotíferos, dez novas ocorrências de cladóceros e dois novos registros de copépodes para o estado do Piauí. A maior riqueza foi observada para os rotíferos, com destaque para o gênero Brachionus, sobretudo no Açude Joana. Entre os crustáceos, foi observada uma maior riqueza no Açude Bezerra, destacando-se os cladóceros do gênero Bosmina. Os rotíferos Brachionus havanaensis Rousselet, 1911 e Filinia longiseta (Ehrenberg, 1834), os cladóceros Diaphanosoma spinulosum Herbst, 1967 e Moina micrura Kurz, 1874, e os copépodes Notodiaptomus cearensis Wright, 1936 e Thermocyclops decipiens Kiefer, 1927 ocorreram em todos 
ou na maioria dos ambientes onde os respectivos grupos foram estudados. Os resultados apresentados aqui ampliam a lista taxonômica do zooplâncton do Estado do Piauí, em uma fauna total de 30 espécies de rotíferos, 15 de cladóceros e três de copépodes. A riqueza do zooplâncton nos ambientes estudados foi considerada baixa em comparação com outros ecossistemas de água doce da Região Nordeste do Brasil; porém, os poucos estudos desenvolvidos na Bacia do Rio Parnaíba sugerem que a diversidade destes organismos seja maior.

Palavras-chave: composição de espécies, zooplâncton, reservatórios, bacia do Rio Parnaíba, Nordeste do Brasil.

\section{Introduction}

Brazil is home to extraordinary biodiversity. However, certain groups, such as those found in inland freshwater ecosystems, are still poorly known. The number of species in these ecosystems is still imprecise and difficult to estimate, due primarily to the number of water basins that have never been inventoried and the small number of surveys that have been performed to date (Agostinho et al., 2005). In the Caatinga biome in particular, the semi-arid climate and the predominance of intermittent rivers and lakes could indicate low diversity among the aquatic biota, with few endemic species and a predominance of generalist, widespread species. However, the few studies available on the plankton of inland waters of the semi-arid region in other northeastern states show that this biome is not poor in species (e.g., Melo Júnior et al., 2007; Almeida et al., 2010; Moura et al., 2010).

Studies on freshwater zooplankton, particularly in the state of Piauí, are almost nonexistent. One of the few studies on the freshwater planktonic rotifers, cladocerans and copepods of this state was conducted by Spandl (1926) in Paranaguá Lake, located in the southernmost region of Piauí. The results of other studies on freshwater zooplankton in the state can be found only in the so-called grey literature, especially course completion work.

As in other regions, the continental aquatic ecosystems of the state of Piauí have experienced constant environmental impact due to the expansion of areas for agricultural and urban occupation. These changes produce water pollution caused by sewage, pesticides and industrial effluents and contribute to the reduction and degradation of the habitats available to the entire biota. Because zooplankton can be an efficient biological tool to manage and to monitor these degraded environments, future recovery programs require an effort to survey the biodiversity of such watersheds. Thus, this study aimed to characterise the zooplankton biodiversity of selected freshwater environments of the Parnaíba basin, semi-arid region of Piauí. The samples for this study were collected approximately 100 years after the only recorded zoological expedition whose results were published. This expedition was conducted in June 1903 and culminated in the paper by Spandl (1926).

\section{Material and Methods}

The Parnaíba River basin extends by the states of Piauí, Maranhão and Ceará, containing large areas of caatinga, rain forest and some agricultural crops. The metropolitan area of Teresina is the main inhabited area of the basin and thus it is where higher impacts occur. Despite the extent of the Parnaíba and its tributaries, the area is characterised by critical indices of water supply, sewerage network and sewage treatment. The basin has more than three thousand miles of perennial rivers, hundreds of ponds and still half the water of the subsoil of the Brazilian Northeast, valued at 10 million cubic metres per year.

Studies to evaluate the zooplankton community were conducted between 2003 and 2007 in seven urban continental water bodies in the state of Piauí: six of them were characterised as lentic (Grande, Bezerra, Joana and Laranjeiras reservoirs, and Nova Brasília and Mocambinho lagoons) and one exhibited lotic conditions (a stretch of the Parnaíba river), all of them located in five municipalities from this State (Figure 1). Each water body had different characteristics, such as the surrounding area, uses and storage capacity (see Table 1).

At least five sampling points were included in the nearshore and limnetic zones, and collections were performed during representative dry-season and rainy-season months. At certain sites, sampling occurred during both seasons, whereas other sites were only sampled during a single season. The samples were collected during the day. A plankton net (44 or $65 \mu \mathrm{m}$ mesh) was used (as shown in Table 1). The net was always towed horizontally beneath the surface of the water. Each plankton tow lasted approximately 5 minutes. The vessel travelled slowly (at a speed of approximately 2 knots).

After sampling, the organisms were fixed with $4 \%$ formaldehyde and transported to the laboratory to be analysed under the stereomicroscope and optical microscope. Each sample was diluted to a known concentration and homogenised. Three $1 \mathrm{~mL}$ aliquots were removed from each sample for subsequent analysis in a Sedgwick-Rafter chamber. The specific literature used for taxonomic identification included Elmoor-Loureiro (1997), Koste (1978), Neumann-Leitão et al. (1989) and Reid (1985). The overall morphology and body dimensions were observed. In addition, specific taxonomic structures were analysed to confirm certain taxa. These analyses included the extraction of the mastax in Rotifera and the dissection of the appendix in microcrustaceans.

A cluster analysis was performed on the Cladocera sample-species data matrix. The Bray-Curtis index was used with the Ward cluster method (Legendre and Legendre, 1998). A cophenetic value matrix was applied to measure the extent to which the clustering result corresponds to the original similarity matrix. This procedure tests the goodness of fit of the cluster analysis results to the data (Rohlf and Fisher, 1968). 


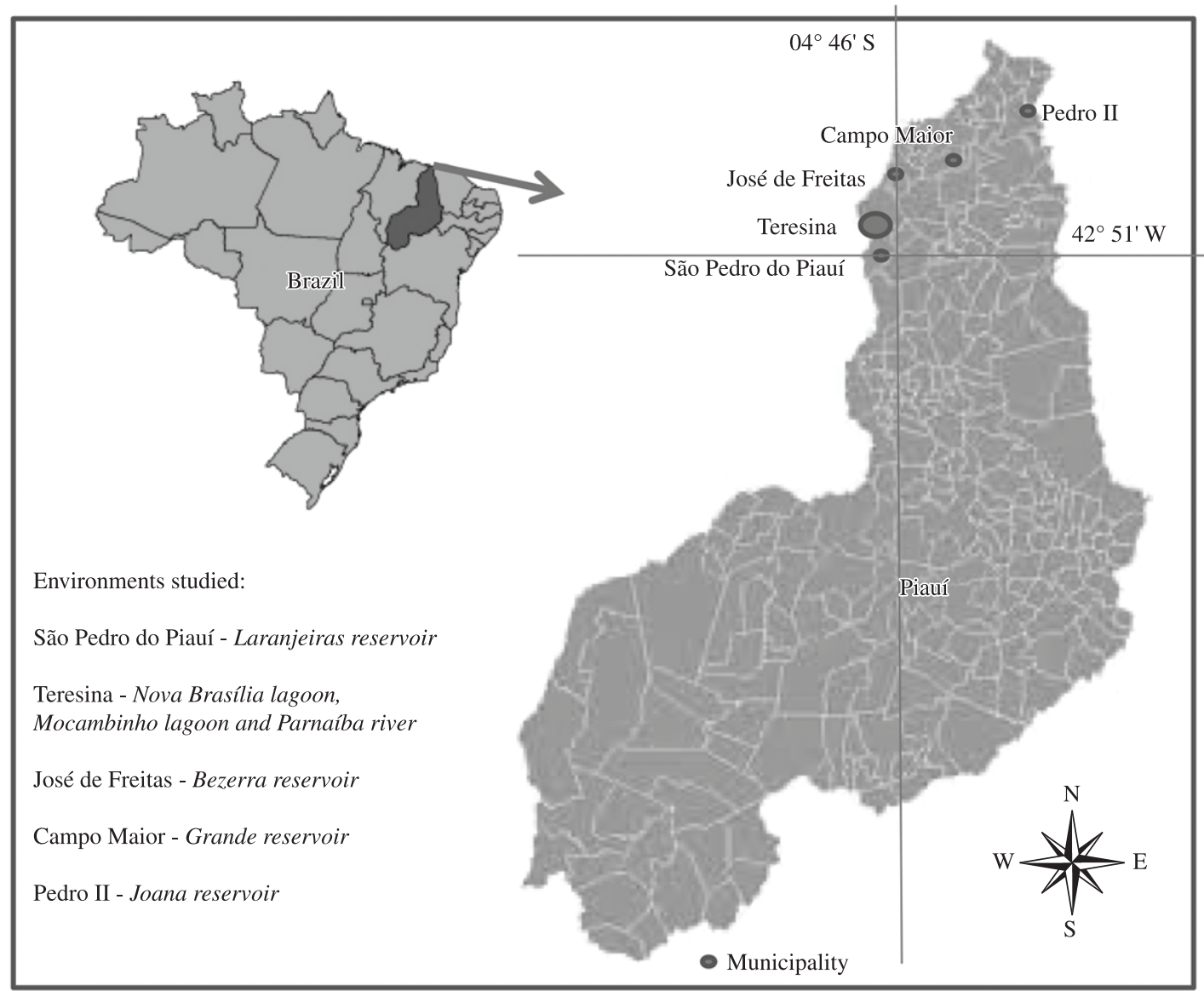

Figure 1. Location of the five municipalities from Piauí, Northeastern Brazil, where the zooplankton of some environments of the Parnaíba basin were studied.

\section{Results}

The taxonomic inventory identified 38 zooplankton species. Rotifers showed the highest richness ( 25 taxa), followed by cladocerans (11) and copepods (2). The following rotifer genera were prominent: Brachionus $(6$ taxa) and Keratella (3), both from the family Brachionidae, as well as Lecane (4), from the family Lecanidae. The richest cladoceran genera were Bosmina (4 taxa), from the family Bosminidae, and Moina (3), from the family Moinidae (see Tables 2 and 3).

The Joana reservoir had the highest specific richness for Rotifera, 13 species, and presented the more frequent occurrence of species from the genus Brachionus as well as the Laranjeiras reservoir. In general, the three environments in which the rotifers were studied showed marked variation in the taxonomic composition, as each ecosystem presented four to nine exclusive taxa. Brachionus havanaensis Rousselet, 1911 and Filinia longiseta (Ehrenberg, 1834) occurred in the three environments studied, whereas Ascomorpha sp., Brachionus falcatus Zacharias, 1898, Brachionus angularis (Gosse, 1851), Keratella americana Carlin, 1943 and Polyarthra vulgaris (Carlin, 1943) were each recorded in at least two ecosystems.
The greatest richness of crustaceans was found at the Bezerra reservoir, where seven species were recorded; moreover, the following three species were exclusively recorded: Bosmina hagmanni (Stingelin, 1904), Bosmina sp. 1 and Bosminopsis deitersi Richard, 1895. Three other taxa were recorded in only one ecosystem each: Bosmina tubicen Brehm, 1953 (only in the Laranjeiras reservoir), Alona sp. (Grande reservoir) and Moina minuta (Hansen, 1899) (Parnaíba river). Bosmina longirostris (O. F. Müller, 1785), Moina reticulata (Daday, 1905) and Moinodaphnia macleayi (King, 1853) occurred in only two reservoirs each, and M. macleayi also occurred in the Parnaíba river. The most common taxa in the seven environments studied were the cladocerans Diaphanosoma spinulosum Herbst, 1967 and Moina micrura Kurz, 1874 and the copepods Notodiaptomus cearensis Wright, 1936 and Thermocyclops decipiens Kiefer, 1927, which occurred in all or in most ecosystems studied.

The cluster analysis of the samples indicated two principal groups (see Figure 2). Group 1 included the Grande reservoir, Nova Brasília and Mocambinho lagoons, and the group 2 included the Joana and Laranjeiras reservoirs. The Parnaíba river and Bezerra reservoir were each isolated. 


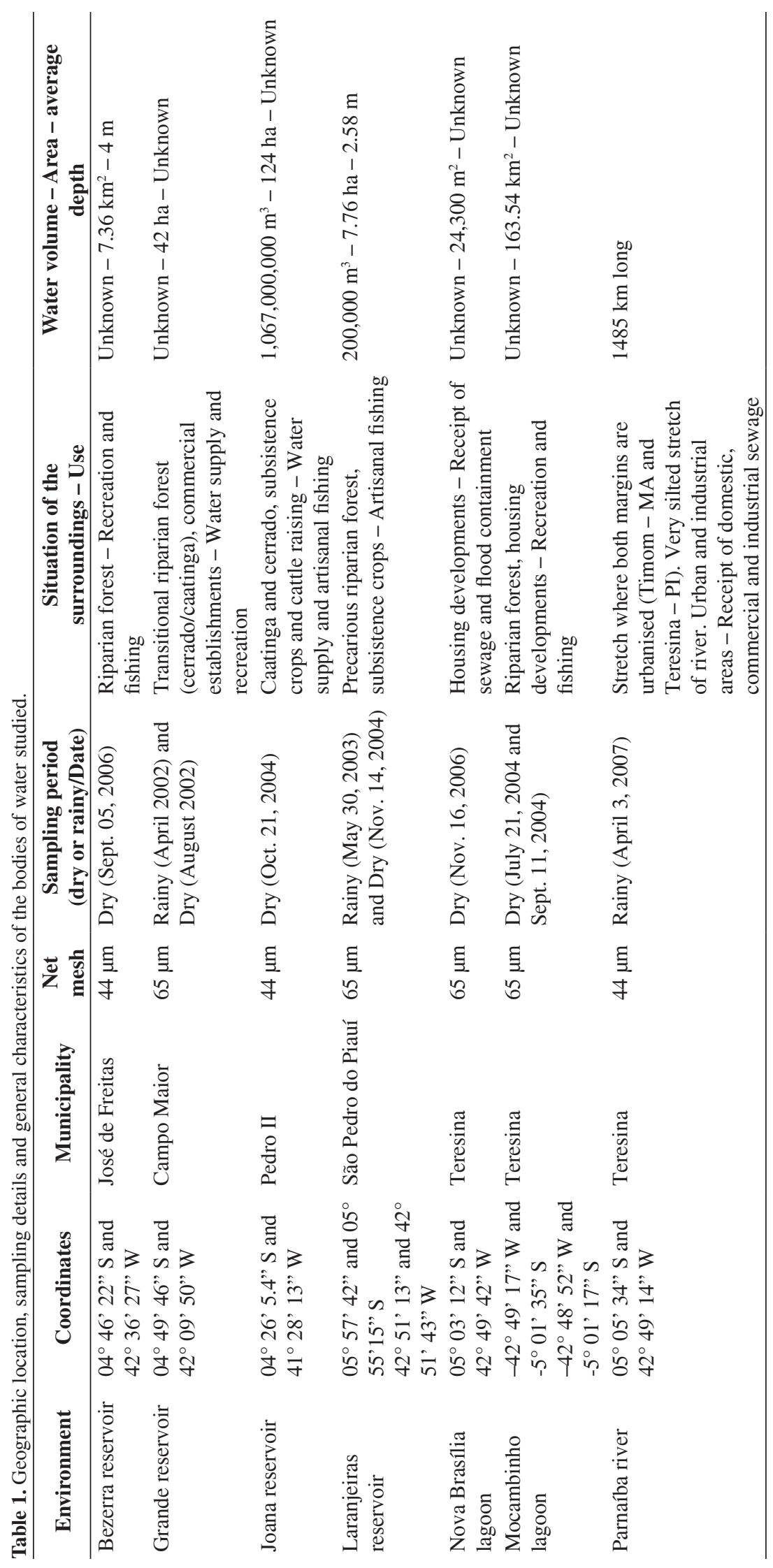


Table 2. Planktonic Rotifera from some reservoirs of Parnaíba basin, Piauí, Northeastern Brazil.

\begin{tabular}{|c|c|c|c|}
\hline Taxa & Grande reservoir & Joana reservoir & Laranjeiras reservoir \\
\hline Anuraeopsis fissa Gosse, 1851 & & + & \\
\hline Anuraeopsis navicula Rousselet, 1911 & & + & \\
\hline Ascomorpha sp. & & + & + \\
\hline Asplanchna sp. & & & + \\
\hline Brachionus angularis Gosse, 1851 & & + & + \\
\hline Brachionus calyciflorus Pallas, 1766 & + & & \\
\hline Brachionus caudatus Barrois \& Daday, 1894 & & & + \\
\hline Brachionus dolabratus Harring, 1914 & & + & \\
\hline Brachionus falcatus Zacharias, 1898 & & + & + \\
\hline Brachionus havanaensis Rousselet, 1911 & + & + & + \\
\hline Collotheca sp. & + & & \\
\hline Epiphanes macroura (Barrois \& Daday, 1894) & + & & \\
\hline Filinia longiseta (Ehrenberg, 1834) & + & + & + \\
\hline Hexarthra sp. & + & & \\
\hline Keratella americana Carlin, 1943 & & + & + \\
\hline Keratella tropica (Apstein, 1907) & & + & \\
\hline Keratella sp. & + & & \\
\hline Lecane bulla (Gosse, 1851) & + & & \\
\hline Lecane leontina (Turner, 1892) & & & + \\
\hline Lecane lunaris (Ehrenberg, 1832) & + & & \\
\hline Lecane perplexa (Ahlstrom, 1938) & + & & \\
\hline Platyias quadricornis (Ehrenberg, 1832) & & & + \\
\hline Polyarthra vulgaris Carlin, 1943 & & + & + \\
\hline Testudinella patina (Hermann, 1783) & & + & \\
\hline Trichocerca $\mathrm{sp}$ & + & + & \\
\hline Specific richness & 11 & 13 & 11 \\
\hline
\end{tabular}

The cluster analysis of the rotifer species yielded three groups. Group 1 included species occurring in Joana reservoir. Group 2 included species occurring in Laranjeiras reservoir and certain species that also occurred in Joana reservoir. Group 3 included species occurring in Grande reservoir and cosmopolitan species (as shown in Figure 3). On the other hand, the cluster analysis of the cladoceran species also yielded three groups. Group 1 was formed by cosmopolitan (Moina micrura) and/or Neotropical species (Diaphanosoma spinulosum and Moina reticulata), and those occurring in Nova and Mocambinho. Group 2 was formed by resilient species occurring in the polluted Parnaiba river, and Group 3 was formed by species occurring primarily in Bezerra reservoir (see Figure 4).

\section{Discussion}

Since Spandl's (1926) inventory of freshwater zooplankton at Paranaguá lake (southernmost region of Piauí), and with the exception of the records available in the grey literature, no surveys conducted in the state's continental bodies of water have been reported. Spandl (1926) recorded seven species of rotifers [Asplanchna brightwellii, Triathra longiseta (= Filinia longiseta), Tetramastix opoliensis (= Filinia opoliensis), Pedalion fennicum (= Hexarthra fennica), Brachionus falcatus, Noteus quadricornis (= Platyias quadricornis) and Anuraea cochlearis (= Keratella colchlearis)], six species of cladocerans (Diaphanosoma sarsi, Ceriodaphnia cornuta, Ceriodaphnia paradoxa, Moina minima (= Moina minuta), Alona reiseri (= Alona monacantha) and Camptocercus sp.) and one copepod [Diaptomus deitersi (= Notodiaptomus deitersi)].

Based on Spandl's (1926) inventory and on the survey presented here, the plankton fauna of the state of Piauí now includes 30 species of rotifers, 15 cladocerans, and 3 copepods. Adding to the findings represented by this previous report, this study presents 23 new occurrences of rotifers for the state, 10 of cladocerans, and two of copepods. Nevertheless, the total number of freshwater zooplankton species of Piauí is low when compared to other freshwater environments of northeastern Brazilian states (Almeida et al., 2010) and of other regions of the country (Matsumura-Tundisi, 1999). According to the descriptions of geographical distribution, the taxa found in the freshwater environments of the state of Piauí are typical of tropical 
Paranhos, JDN. et al.

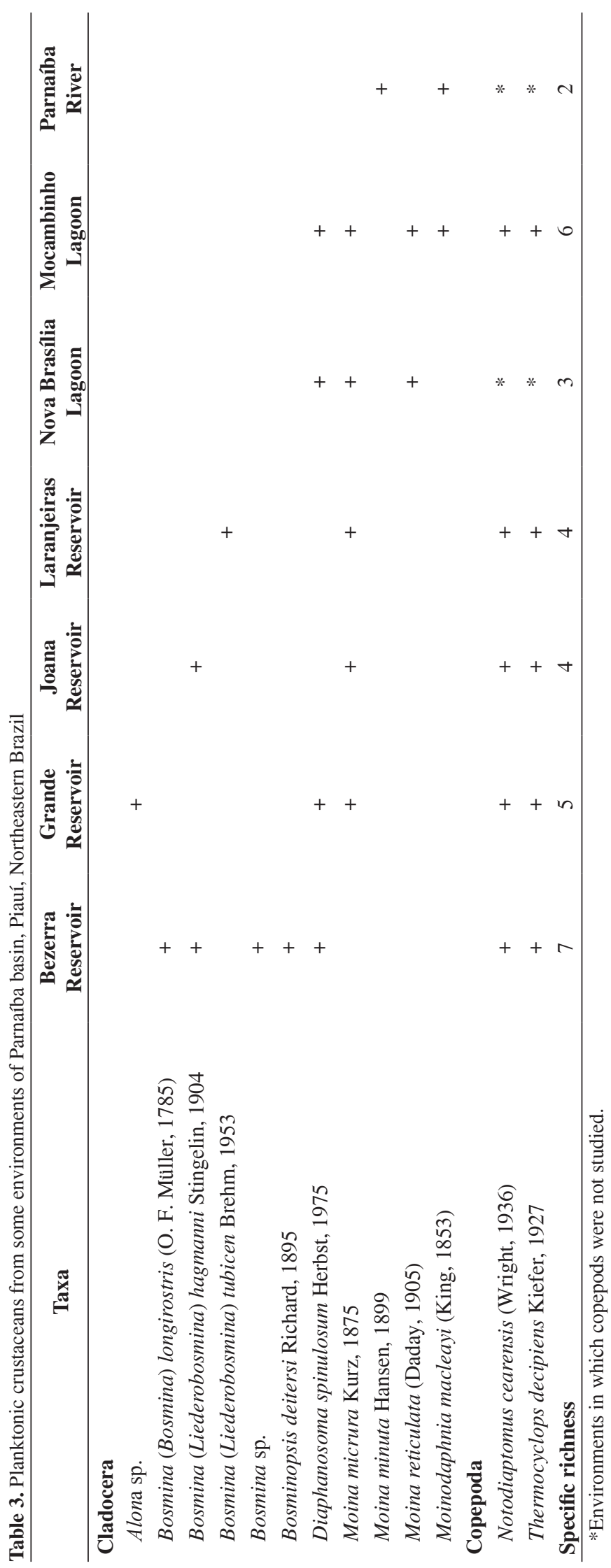




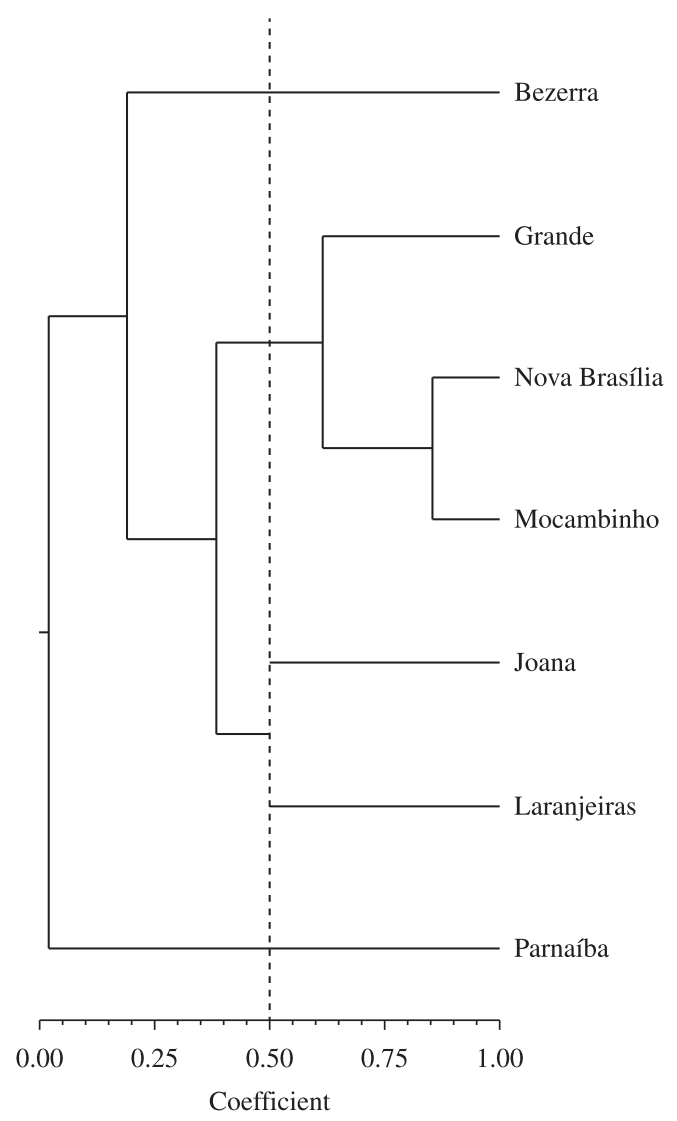

Figure 2. Cluster analysis of samples of freshwater environments of Parnaíba basin, Piauí, Northeastern Brazil, based on Cladoceran species. environments, many of them have circumtropical and/or worldwide distributions, and just three species are distributed in Neotropical region (Diaphanosoma spinulosum, Moina minuta and Notodiaptomus cearensis) (e. g., MatsumuraTundisi, 1999; Segers, 2007; Kotov et al., 2009).

In general, the zooplanktonic richness found in the environments studied in the state of Piauí is lower than that recorded in the water bodies of other northeastern Brazilian states for both rotifers and microcrustaceans (Almeida et al., 2006, 2010). Several factors may be associated with this result, such as the distinctive traits of the environments studied (e.g., hydrodynamics, trophic state, and pollution). However, the collection of the samples at particular times (rather than continuously) appears to be the primary reason for this result.

Thus, the small number of zooplankton species found in Piauí's freshwater environments may be due to the sampling effort, which was relatively small in terms of time. Compared with the number of zooplankton species found in other tropical Brazilian reservoirs, the number of species recorded here is close to that observed in studies based on a few samples (Almeida et al., 2006; Leitão et al., 2006; Eskinazi-Sant'Anna et al., 2007; Melo Júnior et al., 2007). In such studies, sampling generally occurred a few times during the year, and long time intervals separated the samples. Despite the importance of these studies for evaluating the planktonic fauna, the lack of continuity hinders attempts to determine the true taxonomic composition of freshwater environments because it causes many of the rare species to be overlooked. Such species are extremely important for the environmental health of these ecosystems.

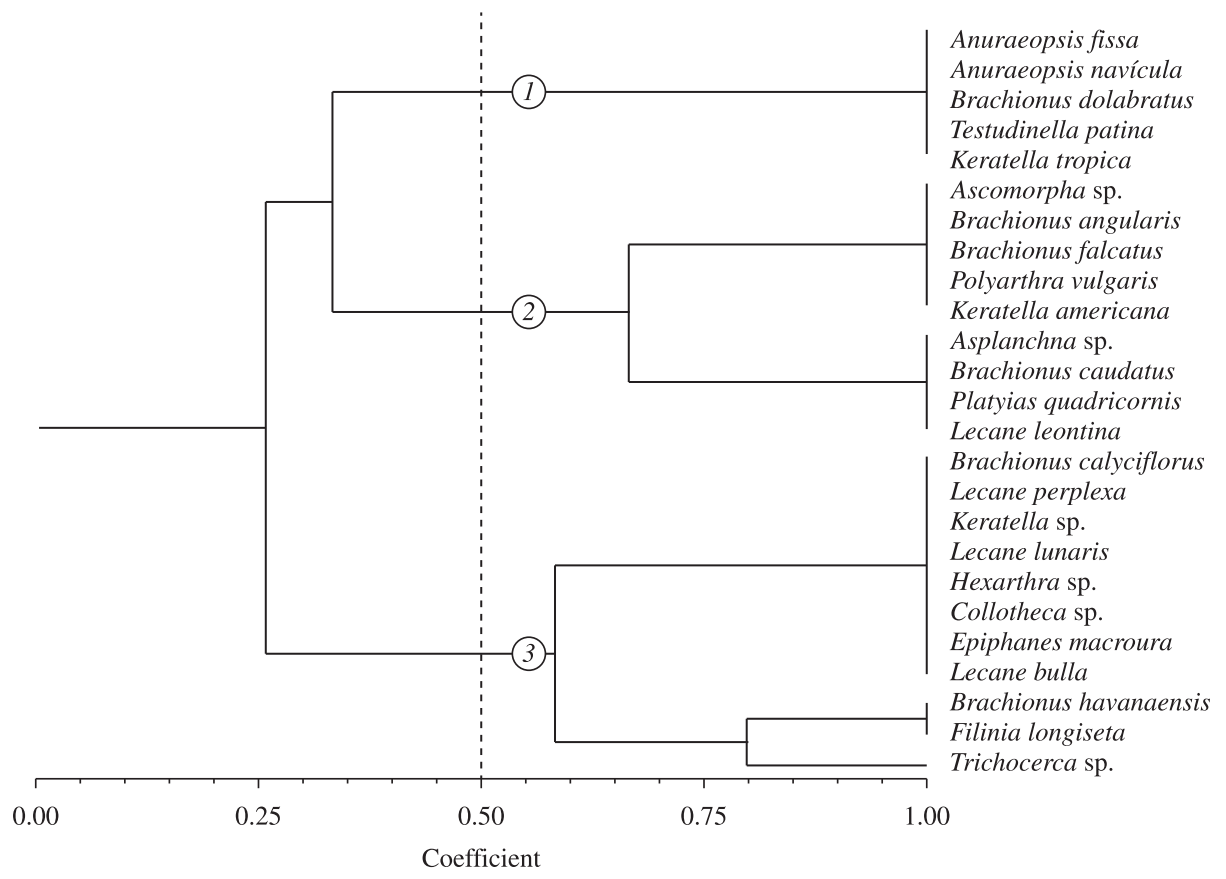

Figure 3. Cluster analysis of Rotifera species of freshwater environments of Parnaíba basin, Piauí, Northeastern Brazil. 


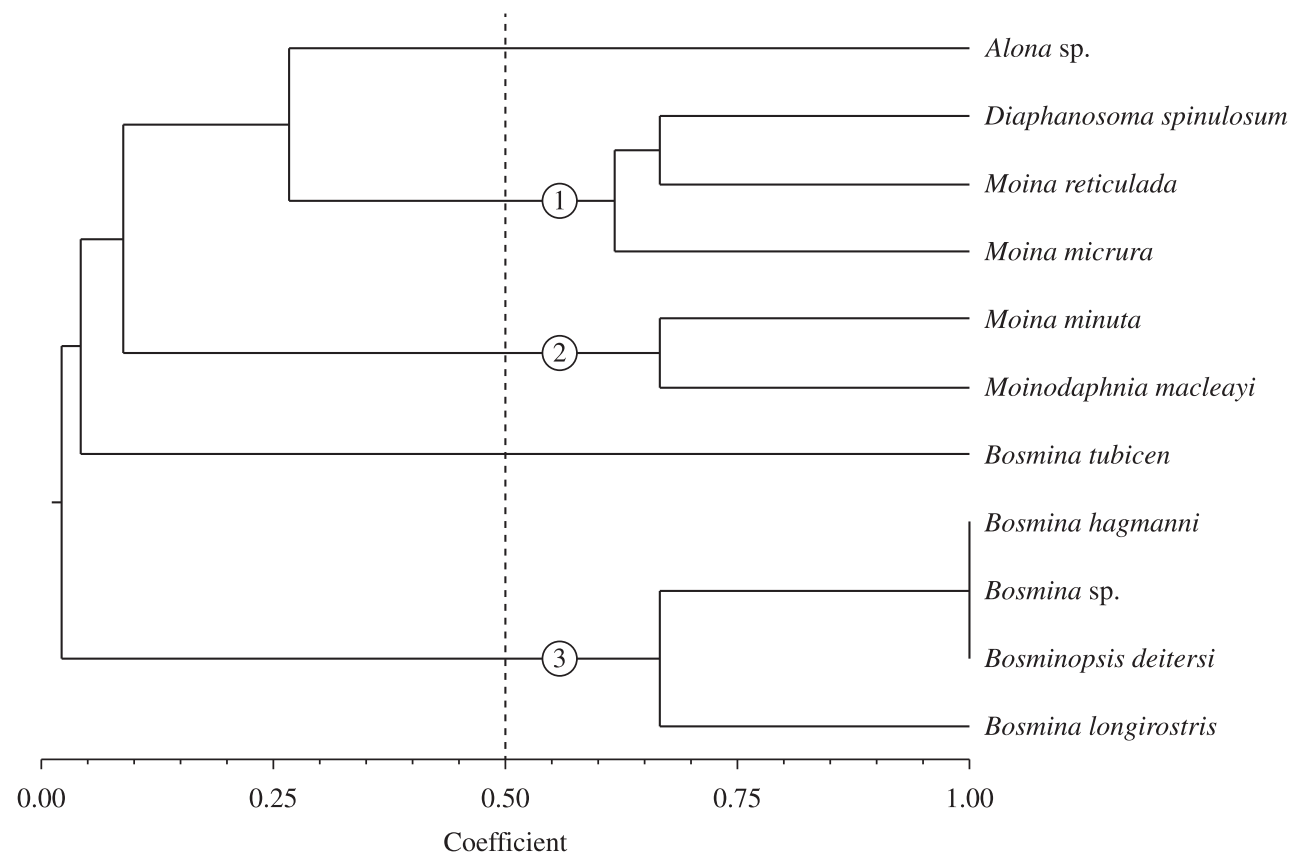

Figure 4. Cluster analysis of Cladocera species of freshwater environments of Parnaíba basin, Piauí, Northeastern Brazil.

Conversely, in studies that are based on a greater sampling effort, including several visits to the field, more species are inventoried, especially rare species. Despite the great richness of species that has now been confirmed for the zooplankton community of reservoirs in the state of São Paulo (Sampaio et al., 2002; Lucinda et al., 2004; Matsumura-Tundisi and Tundisi, 2005; Sartori et al., 2009), Arcifa (1984) only recorded a small number of species from 10 reservoirs of this state. This result was most likely due to the sampling strategy, which was based on only four sampling events.

However, we must not disregard the hypothesis that northeastern Brazilian freshwater environments are naturally low in species biodiversity compared to those of other regions of the country. This difference may be linked to the weak seasonality of the region, which in turn is related to the slight monthly variation in temperature. Even so, the strong temporal variation in precipitation in northeastern Brazilian can be an important environmental force on zooplankton diversity. Even so, in a study carried out in five reservoirs of this area (semi-arid region of Rio Grande do Norte state), Eskinazi-Sant'Anna et al. (2007) found that the composition of the zooplanktonic community does not change significantly over the seasons. These authors suggest that this characteristic is common to other ecosystems of the region and that the environments studied show temporal regularities in the taxonomic structure of the zooplankton, with no apparent seasonal deviations. For Pernambuco, Neumann-Leitão et al. (1989), Almeida et al. (2006) and Melo Júnior et al. (2010) have also found similar patterns of reduced temporal variation in the species composition of the Apipucos, Tapacurá and Jucazinho reservoirs. In all of these environments, the variation in species composition is substantially reduced. In contrast, the relative abundance of the principal species shows more pronounced changes.

A greater richness and density of rotifers are generally found in Brazilian freshwater environments (e. g., Sampaio et al., 2002; Panarelli et al., 2003). These organisms are crucial in continental food webs because they occupy the niche of small filter feeders and transfer the energy of the producers to higher trophic levels (Almeida et al., 2006, 2010). The success of rotifer populations in freshwater environments is due to its limnetic origin, its ability to adapt to changes in the water's physical-chemical variables and the resistance of several taxa to conditions of hypoxia and anoxia. Parthenogenetic reproduction, a short life cycle and the ability to form resistant cysts also favour the group's success (Almeida et al., 2010).

Among the copepods, most of the individuals found in the environments studied were immature forms, i.e., nauplii and copepodites. Such a predominance of immature forms of copepods within the zooplanktonic community has also been reported by other authors (e.g., Bonecker et al., 2001; Almeida et al., 2009; Cardoso and Marques, 2009) and is generally linked to the high mortality rates of nauplii and copepodites and to predation on adults by planktivorous fish.

Most of the species recorded are truly planktonic taxa that can inhabit all portions of a given body of water. However, the genera Lecane, Trichocerca (Rotifera) and Alona (Cladocera) are considered non-planktonic phytophilous organisms. Their occurrence is primarily related to the presence of vegetation in the near-shore regions of aquatic environments (Maia-Barbosa et al., 2008; Sousa and Elmoor-Loureiro, 2008) or to the trophic level of the environments. Rotifers are dominant regardless of trophic 
conditions as they are favoured in environments that range from oligotrophic to eutrophic (Tundisi and MatsumuraTundisi, 2008). Nevertheless, this group is prominent primarily in nutrient-rich environments (such as eutrophic reservoirs) (Duggan et al., 2001; Nogueira, 2001). This observation can explain the greater diversity of pollution indicator species in the Joana and Laranjeiras reservoirs, both of which have undergone major environmental changes.

Our results showed the higher influence of water quality and human impacts on the Parnaiba basin reservoirs. The Cluster analysis separated the environments by the cladoceran species that indicates different human disturbances. Group 1 in the cluster analysis was formed by ecosystems already receiving organic pollution from human settlements (Grande, Nova Brasília and Mocambinho reservoirs); and, group 2 included those with lower human impacts (see Table 1). All these environments showed the occurrence of few cladoceran species or the presence of some Moinidae species, in particular Moina micrura, which generally indicates eutrophic systems. The Parnaíba river and Bezerra reservoir, which were isolated in the Cluster analysis, exhibit unique characteristics. The Parnaíba river is located in Teresina city area, being subject to high levels of urbanization and pollution, while the Bezerra reservoir is exposed to lower human impacts. The greater richness of microcrustaceans observed at this last environment, where seven species were recorded, suggests a lower trophic level and lower pollution when compared with the others. The absence of Moina micrura, a cladoceran typically dominant in eutrophic environments (Almeida et al., 2010), also support this idea.

Certain studies have shown that reservoirs with a high water residence time support a greater number of species (Tundisi et al., 1991; Tundisi and Straskraba, 1999), although this characteristic might not be valid for the northeastern Brazilian semi-arid region. In this region, certain water parameters, such as salinity, turbidity and dissolved oxygen, show substantial variation. Although it was not possible to measure the principal environmental variables in the environments studied here, studies show that semi-arid freshwater environments are high in salinity and turbidity and low in oxygen (Tundisi and Straskraba, 1999) due to the low rates of rainfall and the high rates of solar irradiation for most of the year. Thus, the values of these parameters can become more pronounced over time until the rainfall and climatic conditions change. In these extreme conditions with little temporal variation, semi-arid freshwater environments do not appear to allow the establishment of a large number of species. Therefore, we suggest that further studies should be performed over a longer and continuous period of time rather than in the typical manner (i.e., isolated sampling events throughout the year, considering the dry and rainy seasons) and that shorter intervals (i.e., hours or days instead of weeks and months) should be emphasized in the sampling strategies used in future research.

\section{References}

AGOSTINHO, AA., THOMAZ, SM. and GOMES, LC., 2005. Conservação da biodiversidade em águas continentais do Brasil. Megadiversidade, vol. 1, no. 1, p. 70-78.

ALMEIDA, VLS., DANTAS, ÊW., MELO JÚNIOR, M., BITTENCOURT-OLIVEIRA, MC. and MOURA, AN., 2009. Zooplanktonic community of six reservoirs in Northeast Brazil. Brazilian Journal of Biology, vol. 69, no. 1, p. 79-87.

ALMEIDA, VLS., LARRAZÁBAL, MEL., MOURA, AN. and MELO JÚNIOR, M., 2006. Rotifera das zonas limnética e litorânea do reservatório de Tapacurá, Pernambuco, Brasil. Iheringia, Série Zoologia, vol. 96, no. 4, p. 445-451.

ALMEIDA, VLS., MELO JÚNIOR, M., PARANAGUÁ, MN., LARRAZABAL, ME. and MELÃO, MGG., 2010. O Zooplâncton de Água Doce e seu Estudo em Reservatórios do Nordeste do Brasil. In MOURA, NA., ARAÚJO, EL., BITTENCOURT-OLIVEIRA, MC., PIMENTEL, RMM. and ALBUQUERQUE, UP. (Orgs.). Reservatórios do Nordeste do Brasil: Biodiversidade, Ecologia e Manejo. Bauru: Canal6. p. 441-475.

ARCIFA, MS., 1984. Zooplankton composition of ten reservoirs in southern Brazil. Hydrobiologia, vol. 113, p. 137-145. http:// dx.doi.org/10.1007/BF00026600

BONECKER, CC., LANSAC-TÔHA, FA., VELHO, LFM. and ROSSA, DC., 2001. The temporal distribution pattern of copepods in Corumbá reservoir, state of Goiás, Brazil. Hydrobiologia, vol. 453454, p. 375-384. http://dx.doi.org/10.1023/A:1013142101266

CARDOSO, LS. and MARQUES, DM., 2009. Hydrodynamicsdriven plankton community in a shallow lake. Aquatic Ecology, vol. 43, p. 73-84. http://dx.doi.org/10.1007/s10452-007-9151-x

DUGGAN, IC., GREEN, JD. and SHIEL, RJ., 2001. Distribution of rotifers in North Island, New Zealand, and their potential use as bioindicators of lake trophic state. Hydrobiologia, vol. 446, p. 155-164. http://dx.doi.org/10.1023/A:1017503407240

ELMOOR-LOUREIRO, LMA., 1997. Manual de identificação de cladóceros límnicos do Brasil. Brasília: Universa. 156 p.

ESKINAZI-SANT'ANNA, EM., MENEZES, R., COSTA, IS., PANOSSO, RF., ARAÚJO, M. and ATTAYDE, JL., 2007. Composição da comunidade zooplanctônica em reservatórios eutróficos do semi-árido do Rio Grande do Norte. Oecologia Brasiliensis, vol. 11, p. 410-421. http://dx.doi.org/10.4257/ oeco.2007.1103.10

KOSTE, W., 1978. Rotatoria: die Rädertiere Mitteleroupas Ein Bestimmungswerk begrüdet von Max Voigt. Uberordnung Monogonta. Berlim: Gebrüder Borntraeger. 637 p.

KOTOV, A., FORRÓ, L., KOROVCHINSKY, NM. and PETRUSEK, A., 2009. World checklist of freshwater Cladocera species. Available from: <http://fada.biodiversity.be/group/show/17>. Access in: 02 Apr. 2012.

LEITÃO, AC., FREIRE, RHF., ROCHA, O. and SANTAELLA, ST., 2006. Zooplankton community composition and abundance of two Brazilian semiarid reservoirs. Acta Limnologica Brasiliensis, vol. 18 , p. 451-468.

LEGENDRE, P. and LEGENDRE, L., 1998. Numerical ecology. 2nd English ed. Amsterdam: Elsevier Science. 853 p.

LUCINDA, I., MORENO, IH., MELÃO, MGG. and MATSUMURATUNDISI, T., 2004. Rotifers in freshwater habitats in the Upper 
Tietê River Basin, São Paulo State, Brazil. Acta Limnologica Brasiliensia, vol. 16, no. 3, p. 203-224.

MAIA-BARBOSA, PM., PEIXOTO, RS. and GUIMARÃES, AS., 2008. Zooplankton in littoral waters of a tropical lake: a revisited biodiversity. Brazilian Journal of Biology, vol. 68, no. 4 suppl., p. 1069-1078. PMid:19197477. http://dx.doi.org/10.1590/ S1519-69842008000500014

MATSUMURA-TUNDISI, T., 1999. Diversidade de zooplâncton em represas do Brasil. In HENRY, R., org. Ecologia de reservatórios: estrutura, funcão e aspectos sociais. Botucatu: Fundibio/Fapesp. 800 p.

MATSUMURA-TUNDISI T. and TUNDISI JG., 2005. Plankton richness in a eutrophic reservoir (Barra Bonita Reservoir, SP, Brazil). Hiyrobiologia, vol. 542, p. 367-378. http://dx.doi. org/10.1007/s10750-004-9461-0

MELO JÚNIOR, M., ALMEIDA, VLS., NEUMANN-LEITAO, S., PARANAGUÁ, MN. and MOURA, AN., 2007. O estado da arte da biodiversidade de rotíferos planctônicos de ecossistemas límnicos de Pernambuco. Biota Neotropica, vol. 7, p. 1-9. http:// dx.doi.org/10.1590/S1676-06032007000300013

MELO JÚNIOR, M., ALMEIDA, VLS., PARANAGUÁ, MN. and MOURA, AN., 2010. Zooplâncton do Reservatório de Jucazinho (PE, Brasil): um Olhar sobre um Ecossistema Recém Formado. In MOURA, NA., ARAÚJO, EL., BITTENCOURT-OLIVEIRA, MC., PIMENTEL, RMM. and ALBUQUERQUE, UP. (Orgs.). Reservatórios do Nordeste do Brasil: Biodiversidade, Ecologia e Manejo. Bauru: Canal6. p. 403-440.

MOURA, AN., ARAÚJO, EL., BITTENCOURT-OLIVEIRA, MC., PIMENTEL, RMM. and ALBUQUERQUE, orgs., 2010. Reservatórios do Nordeste do Brasil: biodiversidade, ecologia e manejo. Bauru: Canal6. 575 p.

NEUMANN-LEITÃO, S., NOGUEIRA-PARANHOS, JD. and SOUZA, FBVA., 1989. Zooplâncton do açude de Apipucos. Recife-PE (Brasil). Arquivos de Biologia e Tecnologia, vol. 32, no. 4, p. 803-821.

NOGUEIRA, MG., 2001. Zooplankton composition, dominance and abundance as indicators of environmental compartimentalization in Jurumim reservoir (Paranapanema river), São Paulo, Brazil. Hydrobiologia, vol. 455, p. 1-18. http:// dx.doi.org/10.1023/A:1011946708757
PANARELLI, E., CASANOVA, SMC. and NOGUEIRA, MG., 2003. A comunidade zooplanctônica ao longo de gradientes longitudinais no rio Paranapanema/represa de Jurumim (São Paulo, Brasil). In HENRY, R. (Org.). Ecótonos nas interfaces dos ecossistemas aquáticos. São Carlos: Rima. p. 129-160.

REID, JW., 1985. Chave de identificação e lista de referências bibliográficas para as espécies continentais sulamericanas de vida livre da ordem Copepoda (Crustacea, Copepoda). Boletim de Zoologia, vol. 9, p. 17-143.

ROHLF, FJ. and FISHER, DL., 1968. Test for hierarchical struture in random data sets. Systematic Zoology, no. 17, p. 407-412.

SAMPAIO, EV., ROCHA, O., MATSUMURA-TUNDISI, T. and TUNDISI, JG., 2002. Composition and abundance of zooplankton in the limnetic zone of seven reservoirs of the Paranapanema river, Brazil. Brazilian Journal of Biology, vol. 62, no. 3, p. 525-545. PMid:12530191.

SARTORI, LP., NOGUEIRA, MG., HENRY, R. and MORETTO, EM., 2009. Zooplankton fluctuations in Jurumirim Reservoir (São Paulo, Brazil): a three-year study. Brazilian Journal of Biology, vol. 69, no. 1, p. 1-18. PMid:19347141. http://dx.doi.org/10.1590/ S1519-69842009000100002

SEGERS, H., 2007. Annotated checklist of the rotifers (Phylum Rotifera) with notes on nomenclature, taxonomy and distribution. Zootaxa, vol. 1564, p. 1-104.

SOUSA, FDR. and ELMOOR-LOUREIRO, LMA., 2008. Cladóceros fitófilos (Crustacea, Branchiopoda) do Parque Nacional das Emas, estado de Goiás. Biota Neotropica, vol. 8, no. 1, p. 159-166. http:// dx.doi.org/10.1590/S1676-06032008000100019

SPANDL, H., 1926. Das Zooplankton des Paranagua-sees. Denkschriften der Akademie der Wissenschaften zu Wien. Mathematische-Naturwissenschaftliche Klasse, vol. 76, p. 101-105.

TUNDISI, JG. and MATSUMURA-TUNSDISI, T., 2008. Limnologia. São Paulo: Oficina de Textos. 631 p.

TUNDISI, JG. and STRASKRABA, M. (Eds.). 1999. Theoretical reservoir ecology and its applications. Leiden: Brazilian Academy of Sciences. International Institute of Ecology and Backhuys Publishers. p. 505-528.

TUNDISI, JG., MATSUMURA-TUNDISI, T., CALIJURI, MC. and NOVO, EML de M., 1991. Comparative limnology of five reservoirs in the middle Tietê River, São Paulo State. Verh Internatational Verein Limnology, vol. 24, p. 1489-1496. 